\title{
A comparative study of heavy metal accumulation and antioxidant responses in Jatropha curcas $\mathbf{L}$.
}

\author{
Devi Chinmayee $\mathrm{M}^{1}$, Anu M. $\mathrm{S}^{2}$, Mahesh $\mathrm{B}^{3}$, Mary sheeba $\mathrm{A}^{4}$, Mini $\mathrm{I}^{5}$ and \\ Swapna T. $\mathrm{S}^{6}$ \\ ${ }^{1-6}$ Department of Botany, University College, Thiruvananthapuram, Kerala
}

\begin{abstract}
Jatropha curcas L. commonly known as physic nut or purging nut, is a drought resistant shrub belonging to the family Euphorbiaceae, was analyzed for its accumulation capacity of heavy metals such as lead $(\mathrm{Pb})$, cadmium $(\mathrm{Cd})$ and chromium $(\mathrm{Cr})$. Bioassay was conducted by raising the plant by vegetative propagating the stem cutting in varying concentration of respective heavy metals. The metal concentration in the bioparts of experimental plant revealed that the treated plants accumulated enormous quantity of lead, cadmium and chromium as compared to control plant. The effect of heavy metal stress on antioxidant activity in of J. curcas was investigated. The activity of enzymatic antioxidant such as superoxide dismutase (SOD; E.C. 1.15.1.1) catalase (CAT: EC 1.11.1.6) polyphenol oxidase (PPO; EC 1.14.18.1), peroxidase (POX; E.C. 1.11.1.7) and, phenylalanine ammonia lyase (PAL; E.C.4.3.1.5) were estimated and showed profound variations in response to heavy metal stress from the control plants. Non enzymatic antioxidants such as proline increased with heavy metal concentration and phenol concentration fluctuates. Carotenoids and chlorophyll content found to be reduced with increasing heavy metal concentration. Jatropha curcas L. was capable of self protection against multi-metal stress through activation of various enzymatic and non enzymatic antioxidants.
\end{abstract}

Keywords: Jatropha curcas; Antioxidant enzymes; non-enzymatic antioxidants; Heavy metal stress; Metal accumulation.

\section{Introduction}

The metallic elements with atomic weight more than twenty and those with a relative density greater than $5 \mathrm{~g} \mathrm{~cm}^{-3}$ and specific gravity greater than 4 are considered as heavy metals. Heavy metals occur naturally in the ecosystem with large variations in concentration. Anthropogenic activities cause introduction of heavy metals to ecosystem and cause pollution [1]. Heavy metals that have been identified in the polluted environment include $\mathrm{As}, \mathrm{Cu}, \mathrm{Cd}, \mathrm{Pb}, \mathrm{Cr}, \mathrm{Ni}, \mathrm{Hg}$ and $\mathrm{Zn}$. Heavy metal $\mathrm{Cr}, \mathrm{Cd}$ and $\mathrm{Pb}$ are selected for present study. Lead is phytotoxic at higher concentrations and induces chlorosis, necrosis, stunted root/shoot growth and less biomass production. Chromium is one of the most widely used metals in industry, such as steel production, alloy preparation, wood preservation, leather tanning, paints, pigments, metal plating, tanning, electroplating, steel manufacture and other industrial applications. Cadmium is not an essential metal for plant growth as it can be strongly phytotoxic, causing rapid death. It is known to disturb enzyme activities and inhibit DNA mediated transformation in microbes [2].

To overcome heavy metal toxicity, plant cells are equipped with enzymatic mechanisms to eliminate or reduce their damaging effects. The anti-oxidant enzymes system, mainly including superoxide dismutase (SOD, EC 1.15.1.1), catalase (CAT, EC 1.11.1.6), and peroxidase (POD, EC 1.11.1.7), has the ability to scavenge reactive oxygen species and, thereby, prevent oxidative damage. The function of SOD is to convert superoxide radicals to $\mathrm{H}_{2} \mathrm{O}_{2}$ and the accumulation of $\mathrm{H}_{2} \mathrm{O}_{2}$ is prevented by CAT and G-POX. Thus, the balance between ROS generation and eradication determines the survival of the system. The Ascorbate Peroxidase (APX: EC 1.11.1.11) and Peroxidase (POD; E.C. 1.11.1.7) protects the cell against oxidative damage by $\mathrm{H}_{2} \mathrm{O}_{2}$ toxicity. Non enzymatic compounds like phenolics have free radical scavenging activity that protect membrane lipids from oxidation [3], [4]

Jatropha curcas L. is cultivated as a medicinal plant in many tropical and subtropical countries. It is suitable for preventing soil erosion and shifting of sand dunes. Various parts of the plant hold potential for use as a source of oil, animal feed or medicinal preparations. Recently, their seeds were investigated mainly as a potential source of oil that was recognized as an adequate substitute motor fuel [5]. The goal of the present study was to examine the accumulation of heavy metal and its effect on antioxidant defense enzymes in this plant.

\section{Materials And Methods}

2.1 Bioassay: Pot culture method was adopted for the bioassay. Healthy plants of Jatropha curcas were collected from its natural habit. Threshold level of each metal was estimated and three different treatment concentration (T1, T2, T3) of each metal salt was applied to soil. Garden soil was collected and uniformly 
saturated with varying concentrations of cadmium sulphate $\left(20,30\right.$ and $\left.50 \mathrm{mg} \mathrm{Kg}^{-1}\right)$, lead nitrate $(50,100$ and $\left.150 \mathrm{mg} \mathrm{Kg}^{-1}\right)$, Potassium dichromate $\left(50,75\right.$ and $\left.100 \mathrm{mg} \mathrm{Kg}^{-1}\right)$. The test plants were grown in pots containing 2 $\mathrm{kg}$ garden soil saturated with corresponding concentrations of metal. Untreated soil was used to raise control plants. After one month, plants were harvested, washed with double distilled water, blotted and separated leaves and roots were used for the study.

2.2 Heavy elements: Estimation of the heavy metals (cadmium, lead, and chromium) was carried out following the method of APHA[6]. A known quantity of the sample was subjected to wet digestion using the mixture of concentrated nitric acid and perchloric acid (4:1) for eight hours and made up to a known volume and the solution was aspirated in to Atomic absorption spectrophotometer. The concentration of various heavy metals were computed and expressed as $\mathrm{mg} \mathrm{Kg}^{-1}$.

2.3 Enzymatic antioxidants- The activity of Superoxide dismutase (SOD; E.C. 1.15.1.1) was assayed spectrophotometrically by measuring its ability to inhibit the photochemical reduction of Nitro blue Tetrazoilum [7] One unit of SOD is the amount of extracts that gives $50 \%$ inhibition in the rate of NBT reduction. Catalase activity (CAT; EC 1.11.1.6) was determined by consumption of $\mathrm{H}_{2} \mathrm{O}_{2}$ and was monitored spectrophotometrically at $240 \mathrm{~nm}$ for $3 \mathrm{~min}$ [8]. For Polyphenol oxidase (EC 1.14.18.1) activity, catechol was used and the activity was expressed as changes in absorbance at $495 \mathrm{~nm} \mathrm{~min}^{-1} \mathrm{~g}^{-1}$ fresh weight of tissue [9], For Peroxidase assay (POX; E.C. 1.11.1.7) the increase in absorbance due to oxidation of guaiacol (extinction coefficient $26.6 \mathrm{mM}^{-1} \mathrm{~cm}^{-1}$ ) was monitored at $470 \mathrm{~nm}$ [10]. Phenylalanine ammonia lyase activity was estimated by the method of Brueske et al, [11].

2.4Non- enzymaicantioxidants- Proline was analysed spectrophotometerically at $520 \mathrm{~nm}$ using toluene for a blank as per Bates et al [12]. Chlorophyll Content was measured by Arnon's method [13], total carotenoids as per the procedure of Zakaria et al [14]., and total phenols by Folin-Ciocalteau method [15].

2.5 Statistical analysis: The data concerning the antioxidant activity and metal content were analysed by statistical software SAS (version 9.1)

\section{Result And Discussion}

3.1 Accumulation of heavy metals- The bioassay revealed the concentration of chromium varied from 34 to 171,150 to 288 and 469 to $242 \mu \mathrm{g} \mathrm{g}^{-1}$ in leaves, stem and roots respectively after giving heavy metal treatment. Under normal conditions, concentration of $\mathrm{Cr}$ in plants is less than $1 \mu \mathrm{gg}^{-1}$ [16]. From the data, concentration of chromium was high in the roots followed by stem and leaves (Fig. 1). The cadmium content in the control plants were below detectable levels. Phytoaccumulation of cadmium in the roots $\left(249\right.$ to $\left.839 \mu \mathrm{g} \mathrm{g}^{-1}\right)$ were comparatively higher than leaf (52 to $\left.350 \mu \mathrm{g} \mathrm{g}^{-1}\right)$ and stem $\left(249\right.$ to $\left.839 \mu \mathrm{g} \mathrm{g}^{-1}\right)$. The Jatropha curcas L. plants survived under high concentration of cadmium in the soil with slight variation in the morphological and biochemical parameters. Accumulation of lead was high in the roots followed by stem and leaves. The concentration of lead increased from 359 to $897.33,731.6$ to 767.01 and 975.6 to $1673.3{\mu g ~ g^{-1}}^{1}$ in the leaf, stem and root respectively under lead stress. In the present investigation the greatest accumulation of heavy metal like chromium and cadmium taken up from the soil was found in roots as compared to shoot and leaf. The roots of Jatropha curcas L. was found to be suitable for the uptake of heavy metals in sewage sludge [17]. But in the case of lead greatest accumulation was found in shoot. Thus, Jatropha Curcas L. can be proposed as a phytoremediator and also a hyperaccumulator, especially in the case of lead.

3.2 Superoxide Dismutase: SOD activity of control plant in Jatropha curcas L. (Fig.2) were recorded as 8, 9.2 and $4.3 \mathrm{Ug}^{-1}$ in leaf, stem and root respectively. Cr stressed plant show increased SOD activity in all bioparts. The SOD activity in stem of $\mathrm{Cr}$ treated plant recorded higher concentration $\left(26,54\right.$, and $\left.57 \mathrm{Ug}^{-1}\right)$. The enzyme was distributed almost in equal amount in all biopart of $\mathrm{Cd}$ stressed plant, but SOD activity increased in increased $\mathrm{Cd}$ concentration. $\mathrm{Pb}$ stress enhanced SOD activity in all biopart. Comparatively higher concentration was recorded in leaf $\left(81 \mathrm{Ug}^{-1}\right)$ of Jatropha curcas L on treatment with $150 \mathrm{mgKg}^{-1}$ lead. The increase of SOD activity can be considered as an indirect evidence for enhanced production of free radicals. From the above study Jatropha curcas L. showed increased enzyme activity in all treatment. It has been reported that excess $\mathrm{Cr}$ and Al- increased the activity of SOD in higher plants during oxidative damage [18]; [19]. Cd-induced enhancement in superoxide dismutase (SOD) activity also reported in Pea (Pisum sativum L.) plants [20].

3.3 Catalase: Catalase activity in control plants in Jatropha curcas L. (Fig.3) were 2.5, 0.9 and $1.55 \mathrm{Ug}^{-1}$ in leaf stem and root respectively. As compared to control, Catalase activity was increased in all biopart of heavy metal stressed plant. The leaf of $\mathrm{Cr}$ treated plant showed more catalase activity than stem and root, that follow same

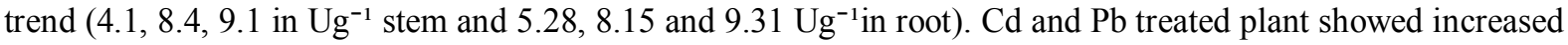
enzyme activity in leaf as compared to root and stem. Comparatively higher concentration was recorded in leaf $\left(50.1 \mathrm{Ug}^{-1}\right)$ of Jatropha curcas L on treatment with $50 \mathrm{mgKg}^{-1}$ cadmium. Cadmium treated Jatropha curcas.L 
recorded more catalase activity than other treatment. In mustard (Sinapis arvensis L.) at the highest concentration of heavy metals, the activity of CAT was higher in $\mathrm{Cd}$ treatment than $\mathrm{Pb}$ treatment [21]. A possible component of a systemic signal is $\mathrm{H}_{2} \mathrm{O}_{2}$ which sets up an acclimatory response in unstressed regions of plants. Lead treated Jatropha curcas.L also showed increasing catalase activity, which may be due to the scavenging role of CAT to $\mathrm{H}_{2} \mathrm{O}_{2}$ [22].

3.4 Peroxidase: The Peroxidase content in control plant of Jatropha curcas L. (Fig.4) ranged from $0.5 \mathrm{ug}^{-1}$ to $1.5 \mathrm{ug}^{-1}$. As compared to control, peroxidase activity increased in all biopart under heavy metal stress. The root of cadmium and lead treated plant showed decreased enzyme activity as treatment concentration increased (50 $\mathrm{mgKg}^{-1}$ cadmium, $150 \mathrm{mgKg}^{-1}$ lead). In Jatropha curcas $\mathrm{L}$ peroxidase activity is increased in all biopart under heavy metal stress. POD activity was also shown to increase under heavy metal stress during late germination and early seedling growth in some annual herbaceous species like Chenopodium rubrum [23] and tomato [24] POD participating in lignin biosynthesis could build up a physical barrier against toxic heavy metals [25].

3.5 Phenylalanine Ammonia Lyase: Phenylalanine Ammonia Lyase (Fig.5) activity in control plant Jatropha curcas L were recorded as $0.0049,0.024$ and 0.002 in stem root and leaf respectively. Chromium stress increases PAL activity in stem and root but reverse trend was noted in leaf. Root of cadmium and lead stressed plant recorded increasing enzyme activity but slight decrease was noted in leaf and stem. Phenylalanine ammonia lyase (PAL) is the first committed enzyme involved in the plant phenylpropanoid pathway [26]. The PAL activity increased in Jatropha curcas L. under heavy metal stress in all bioparts.

3.6 Polyphenol Oxidase: Polyphenol Oxidase activity (Fig.6) recorded in control plant of Jatropha curcas.L were $0.3,0.1 .0 .3 \mathrm{ug}^{-1} \mathrm{ln}$ leaf, stem and root respectively. As compared to control Polyphenol Oxidase activity was increased in all biopart under heavy metal stress. Chromium stress increased Polyphenol Oxidase activity in all bio part as stress increased. In chromium stressed plant higher concentration was recorded on treatment with $100 \mathrm{mgKg}^{-1}\left(1.39,1.25,2.4 \mathrm{ug}^{-1}\right)$. In cadmium and lead treated plant, enzyme activity was increased in root as compared to leaf and stem. In general heavy metals like chromium cadmium and lead increase PPO activity in Jatropha curcas L. especially in root. Saffar [27] reported that in Arabidopsis thaliana PPO activity might be the result from prolonged heavy metal stress.

3.7 Proline- Proline content in control plant (Fig.7) of Jatropha curcas L was $11.927,5.165$ and $2.55 \mathrm{mg} \mathrm{g}^{-1}$ in the leaf stem and root respectively. Cr stress enhanced proline content in leaf while stem and root showed slight decrease and then slight increase with increasing stress $\left(50,75,100 \mathrm{mg} \mathrm{kg}^{-1}\right)$. The leaf and stem of $\mathrm{Cd}$ treated plant showed increasing proline content up to $24.9 \mathrm{mg} \mathrm{g}^{-1}$ in leaf and $13.2 \mathrm{mg} \mathrm{g}^{-1}$ stem, while no change was visible in root. $\mathrm{Pb}$ toxicity enhanced proline content in leaf $\left(19.87\right.$ to $\left.24.96 \mathrm{mg} \mathrm{g}^{-1}\right)$ and stem but root showed slight decreasing trend. $\mathrm{Cr}, \mathrm{Cd}$ and $\mathrm{Pb}$ stress increased proline content in leaf of Jatropha curcas $\mathrm{L}$. but the toxicity did not affect stem and root. Proline can play an important protective role against heavy metal stress. Free proline accumulation under heavy metal exposure seems to be widespread among plants [28].

3.8 Pigment profile. The distribution of photosynthetic pigments displayed variation not only in response to concentration of treatment but among biopartsof Jatropha curcas.L.The finding of variation in chlorophyll content may be due to alteration of chloroplast structure and thylakoid membrane composition under heavy metal stress conditions.

3.9 Chlorophyll-a - Chlorophyll acontent of control (Fig.8) plant were recorded as 0.0071 and $0.00111 \mathrm{mg} \mathrm{g}^{1}$ in the leaf and stem respectively. As compared to control, chlorophyll- a content is increased in stem and leaf as treatment with 50 and $100 \mathrm{mg} \mathrm{Kg}^{-1} \mathrm{Cr}$ while decreased in treatment with $75 \mathrm{mg} \mathrm{Kg}^{-1} \mathrm{Cr}$. Cd stress decrease chlorophyll- a content in leaf while it failed to establish a definite trend in chlorophyll- a content in stem. $\mathrm{Pb}$ toxicity decrease chlorophyll- a content in both stem and leaf.

3.10 Chlorophyll- b- Chlorophyll- b content of control (Fig.9) plant was recorded as 0.005 and $0.0034 \mathrm{mg} \mathrm{g}^{-1}$ in the leaf and stem respectively. The amount of chlorophyll -b increased in leaf $\left(0.009\right.$ to $\left.0.0155 \mathrm{mg} \mathrm{g}^{-1}\right)$ and stem ( 0.00638 to $\left.0.0081 \mathrm{mg} \mathrm{g}^{-1}\right)$ under $\mathrm{Cr}$ stress. Chlorophyll-b also recorded decrease in leaf $\left(0.0011\right.$ to $\left.0.004 \mathrm{mg} \mathrm{g}^{-1}\right)$ as well as stem $\left(0.00013\right.$ to $\left.0.00058 \mathrm{mg} \mathrm{g}^{-1}\right)$ and remained lower than control under cadmium and lead stress.

3.11Total chlorophyll - Total chlorophyll content in control (Fig.10) plant was recorded as 0.0201 and 0.0064 $\mathrm{mg} \mathrm{g}^{-1}$ in the leaf and stem respectively. Total chlorophyll content increased slightly and then decreased in the leaf after treatment irrespective of the concentration of Chromium $\left(50,75,100 \mathrm{mg} \mathrm{kg}^{-1}\right)$ while an increasing 
trend was noticed in the stem. Significant decrease was observed in total chlorophyll in stem (0.0010 to 0.0017 $\left.\mathrm{mg} \mathrm{g}^{-1}\right)$ and leaf $\left(0.005\right.$ to $\left.0.019 \mathrm{mg} \mathrm{g}^{-1}\right)$ under cadmium and lead stress.

3.12Carotenoids- Carotinoid content of control (Fig.11) plant of was recorded as 0.431 and $0.515 \mathrm{mg} \mathrm{g}^{-1}$ in the leaf and stem respectively. Cadmium and chromium enhanced carotenoid content in leaves and stem as compared to control. Carotenoids exhibited slight increasing trend irrespective of the biopart under lead stress.

Heavy metals inhibit chlorophyll and carotenoid biosynthesis, and retard the incorporation of these pigments in photosystems. In this study lead and cadmium stress reduced almost all parameters except carotenoids irrespective of the biopart of Jatropha curcas L. while slight increase was evident under chromium treatment. Cr-treated green gram leaves showed a reduction in contents of $\mathrm{Chl}-\mathrm{a}, \mathrm{Chl}-\mathrm{b}$ and total chlorophyll. Under heavy metal stress condition, rye seedlings showed relatively increasing degradation in the content of Chlorophyll- $\mathrm{a}$ and $\mathrm{b}$ in the detached leaves [29]. Chromium induced disorganization of the chloroplast ultra structure and inhibition of electron transport processes [30]. However, cadmium recorded a decline in photosynthetic pigments in leaf and stem of Jatropha curcas L as compared to control. The reduction of biomass by $\mathrm{Cd}$ toxicity could be the direct consequence of the inhibition of chlorophyll synthesis and photosynthesis [31].

In this study, at higher $\mathrm{Pb}$ concentration, the chlorophyll and carotenoid content decreased with the increasing concentrations of externally supplied $\mathrm{Pb}$ in Jatropha curcas L. This reduction in chlorophyll and carotenoid content of plant under high concentration of $\mathrm{Pb}$ stress can be regarded as a specific response of the plants to metal stress, which resulted in chlorophyll degradation and inhibition of photosynthesis, it was probably caused by interaction of $\mathrm{Pb}$ to $-\mathrm{SH}$ group of enzymes of chlorophyll biosynthesis as well as lipid peroxidation-mediated degradation as indicated by Singh [32]. A similar type of result was reported by Tanyolac [33] with Zea mays L .stressed by $\mathrm{Cu}$.

3.13 Phenol- The concentration of phenol (Fig.12) in the control plants recorded a trend of leaf $>$ stem $>$ root and values were $0.134,0.02$ and $0.013 \mathrm{mg} \mathrm{g}^{-1}$ respectively. As compared to control plants phenolic content in Jatropha curcas $\mathrm{L}$ increased in all bioparts of $\mathrm{Cr}$ and $\mathrm{Pb}$ treated plant. Initial increase followed by decrease was displayed in all biopart of Jatropha curcas L as treatment concentration $\left(50,75,100 \mathrm{mg} \mathrm{kg}^{-1}\right)$ of Cr increased. $\mathrm{Cd}$ stress up to $30 \mathrm{mg} \mathrm{kg}^{-1}$ decreased phenol content of leaf at $0.088 \mathrm{mg} \mathrm{g}^{-1}$ and root at $0.007 \mathrm{mg} \mathrm{g}^{-1}$, but reverse trend was noted in stem. In general Cd in higher concentration $\left(50 \mathrm{mg} \mathrm{kg}^{-1}\right)$ affects phenolic content of plant. In Jatropha curcas L increased phenolic content was visible under all heavy metal stress but Phaseolus vulgaris when exposed to Cd, reported to accumulate soluble and insoluble phenolics [34] and Phyllantus tenellus leaves reported to have more phenolics than control plants.

In plants as in other organisms, heavy metals can severely impair central metabolic processes. One primary target in plants is the photosynthetic apparatus. Heavy metals can inhibit photosynthesis at several structural and metabolic levels. The plant showed both positive and negative co-relation between heavy metal uptake and antioxidant activity shown in fig 13 and 14. Heavy metals cause severe damages in plants and that there are multiple molecular targets of heavy metal damage. But in Jatropha curcas L. lead and cadmium stress reduced pigment content except carotenoids while slight increase was recorded under chromium treatment.

In Jatropha curcas L enzymatic and non-enzymatic antioxidant defense systems played a significant role against heavy metal stress. Jatropha curcas L was able to protect against multi-metal stress through activation of various enzymatic and non enzymatic antioxidants that serves as an important component in antioxidant defense mechanisms.

\section{Conclusion}

Present study supported the hypothesis that Jatropha curcas L had ability to cope with metal stress depends on oxidative stress defense mechanisms. Changes in, SOD, CAT, POX, PPO and PAL showed a clear correlation with heavy metal concentrations. It can be concluded that heavy metal causes oxidative stress as evidenced by the decrease in the chlorophyll and carotenoid content. The data demonstrated a significant increment in the activities of major antioxidant enzymes, which are involved in the detoxification of ROS. Cr, $\mathrm{Cd}$ and $\mathrm{Pb}$ stress increased proline content in leaf of Jatropha curcas.L. Cadmium and chromium enhanced carotenoid content in leaves and stem as compared to control. The distribution of photosynthetic pigments displayed variation not only in response to concentration of treatment but among bioparts. Jatropha curcas L was able to protect against multi-metal stress through activation of various enzymatic antioxidants that serves as an important component in antioxidant defense mechanisms. Jatropha curcas L. proposed as a suitable plant to use as a phytoremediator due to its high tolerance and hyperaccumulation. 


\section{Acknowledgements}

Authors are thankful to the Department Of Environment and Climate Change, Govt. of Kerala for providing financial support

\section{References}

[1] McGrath, S.P., Zhao, F.J., Lombi, E., Plant and rhizosphere process involved in phytoremediation of metal-contaminated soils, Plant Soil, 232(1/2), 2001, 207-214.

[2] Pendias, K A and Pendias, H. Trace elements in soil. CRC Press, London 2001.

[3] Sanita di Toppi L and Gabbrielli R Response to cadmium in higher plants, Envir.Exp. Bot. 41, 1999, 105-130.

[4] Sandalio L M, Dalurzo H C, Gomez M, Romero Puertas M C and Rio L A, Cadmium-induced changes in the growth and oxidative metabolism of pea plants. J. Exp. Bot. 52(364), 2001, 2115-2126.

[5] Openshaw K. A review of Jatropha curcas: an oil plant of unfulfilled promise, Biomass Bioenergy, 19, 2000: 1-15.

[6] APHA, Standard methods for the examination of water and waste water. 18(Ed), APHA-AWWA-WPCF, 1992.

[7] Beauchamp C H and Fridovich I, Superoxide dismutase: improved assays and an assay applicable to acrylamide gels. Analytical Biochemistry 44, 1971, 276-87.

[8] Luck H, Methods in Enzymatic Analysis, 2nd edition, Bergmeyer, Academic Press, New York, 1974.

[9] Esterbauer H, Schwarzl E and Hayn M, A rapid assay for catechol oxidase and laccase using 2, nitro-5-thiobenzoic acid, Anal. Biochem., 77 , 1977. 486-494.

[10] Putter, J. In: Methods of Enzymatic Analysis, 2 (Ed. Bergmeyer), Academic Press, New York, (1974).

[11] Bruske C H, Phenylalanine ammonia lyase activity in tomato roots infected and resistant to the root-knot nematode (Meloidogyne incognita) Physiol. Pl. Path. 16 1980, 409-414.

[12] Bates L S, Waldren R P and Teare I D, Rapid determination of free proline for water stress studies. Plant Soil, Vol. 39, 1973, 205207.

[13] Arnon, D.I. Copper enzymes in isolated chloroplasts: polyphenol oxidase in Beta vulgaris. Plant Physiol.24, $1949,1-15$.

[14] Zakaria, H., K. Simpson, P. R. Brown and A. Krotulovic, Use of reversed phase HPLC analysis for the determination of provitamin A, carotenes in tomatoes. J. Chromatography, 176, 1979, 109-117.

[15] Malick, C.P and Singh, M.B, ln:plant enzymology and histoenzymology, Kalyani publishers, New Delhi, 1980.

[16] Mortvedt. J. J., Giordano P. M., "Response of corn to zinc and chromium in municipal wastes applied to soil," Journal of Environmental Quality, 4, 1975, 170-174.

[17] Parisa Ahmadpour., Hazandy Abdul-Hamid, Uptake of Heavy Metals by Jatropha curcas L. Planted in Soils Containing Sewage Sludge. American Journal of Applied Sciences .7 (10) 2010 1291-1299.

[18] Chongpraditnum P, Mori S, Chino M , Excess copper induce a cytosolic Cu, Zn superoxide dismutase in soybean root. Plant Cell Physiol. 33 ,1992, 239-244.

[19] Karuppanapandian T, Pritam BS, Kamarul HA, ManoharanK, Differential antioxidative responses of ascorbate-glutathione cycleenzymes and metabolites to chromium stress in green gram (Vigna radiate L.) leaves. J. Plant Biol. 49(6), $2006,440-447$.

[20] Vivek Dixit, Vivek Pandey ,Radhey Shyam, Differential antioxidative responses to cadmium in roots and leaves of pea (Pisum sativum L. cv. Azad) Journal of Experimental Botany. 52, 2001, 1101-1109

[21] Mostafa Heidari., Semin Saran, Effects of lead and cadmium on seed germination, seedling growth and antioxidant enzymes activities of mustard (Sinapis arvensis L.) Journal of Agricultural and Biological Science 6, 2001, 6-11.

[22] Elstner, E. F., G. A. Wagner and W. Schutz, Activated oxygen in green plants in relation to stress situations. Current Topics in Plant Bioche and Phy. 7, 1988,159-189.

[23] Ducic T, Liric-Rajlić I, Mitrovic A, Radotic K, Activities of antioxidant systems during germination of Chenopodium rubrum seeds. Biol. Plant.47, 2003, 527-533.

[24] Morohashi Y. (2002). Peroxidase activity develops in the micropylar endosperm of tomato seeds prior to radicle protrusion. J. Exp. Bot. 53, 2002, 1643-1650.

[25] Dong J, Wu FB, Zhang GP, Influence of cadmium on antioxidant capacity and four microelement concentrations in tomato seedlings (Lycopersicon esculentum). Chemosphere,64, 2006, 1659-1666.

[26] Amrita, K. and E.E. Brian, The phenylalanine ammonialyase gene family in raspberry, structure, expression, and evolution. Plant Physiol., 127: 2001, 230-239.

[27] Saffar, M.B. Bagherieh Najjar and Mianabadi,.M, Activity of Antioxidant Enzymes in Response to Cadmium in Arabidopsis thaliana. Journal of Biological Sciences,9: 2009,44-50.

[28] Costa G, Morel J.L, Water relations, gas exchange and aminoacid content in Cd-treated lettuce. Plant Physiol. Biochem. 32, 1994, 561-570.

[29] Krupa Z, Oquist G, Hunner NPA, The effects of cadmium on photosynthesis of Phaseolus vulgaris - a fluorescence analysis. PhysiologiaPlantarum 88, 1993, 626-630.

[30] Shanker AK, Cervantes C, Loza-Tavera H, Avudainayagam S, Chromium toxicity in plants. Environment International 31, 2005, 739-753.

[31] Padmaja, K., Prasad, D.D.K., Prasad, A.R.K., Inhibition of chlorophyll synthesis in Phaseolus vulgaris Seedlings by cadmium acetate. Photosynthetica 24, 1990 399-405.

[32] Singh S, Eapen S, Souza SF, Cadmium accumulation and its influence on lipid peroxidation and antioxidative system in an aquatic plant, Bacopa monnieri L. Chemosphere 62, 2006, 233-246

[33] Tanyolac D, Ekmekc Y, Unalan S, Changes in photochemicaland antioxidant enzyme activities in maize (Zea mays L.) leavesexposed to excess copper. Chemosphere 67, 2007, 89-98.

[34] Smeets K., Cuypers A., Lambrechts A., Semane B., Hoet P., Van Laere A., Vangronsveld J, Induction of oxidative stress and antioxidative mechanisms in Phaseolus vulgaris after Cd application. Plant Physiol.Biochem.43, 2005437. 

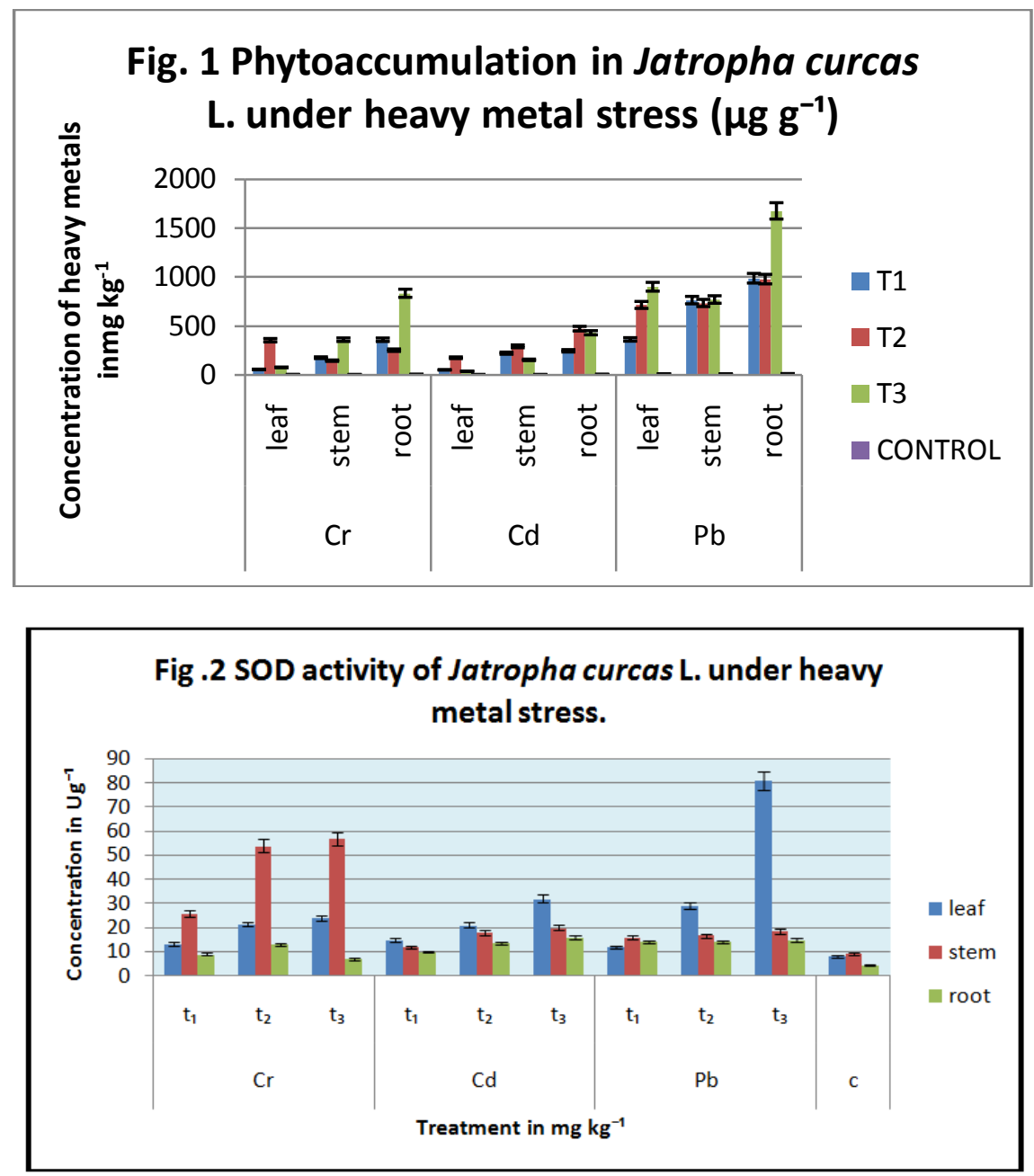

Fig.3 Catalase activity of Jatropha curcas L. under heavy metal stress.

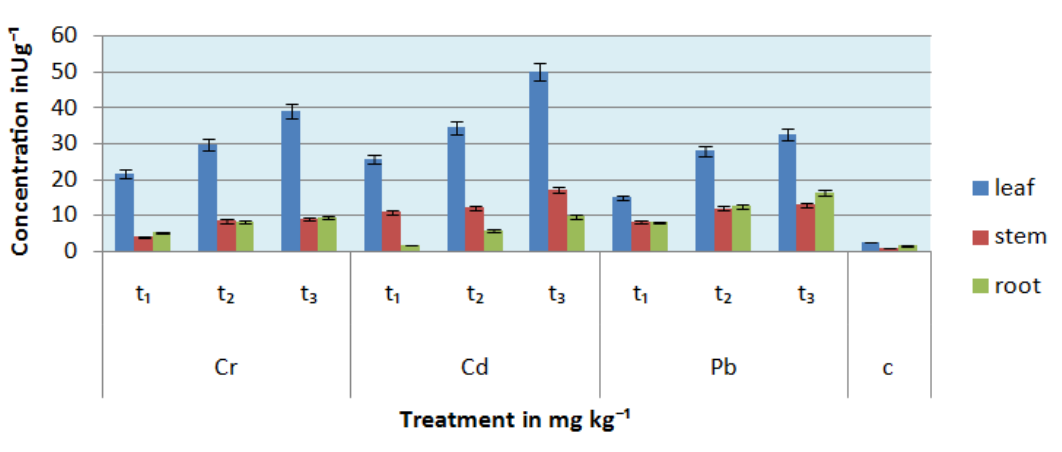



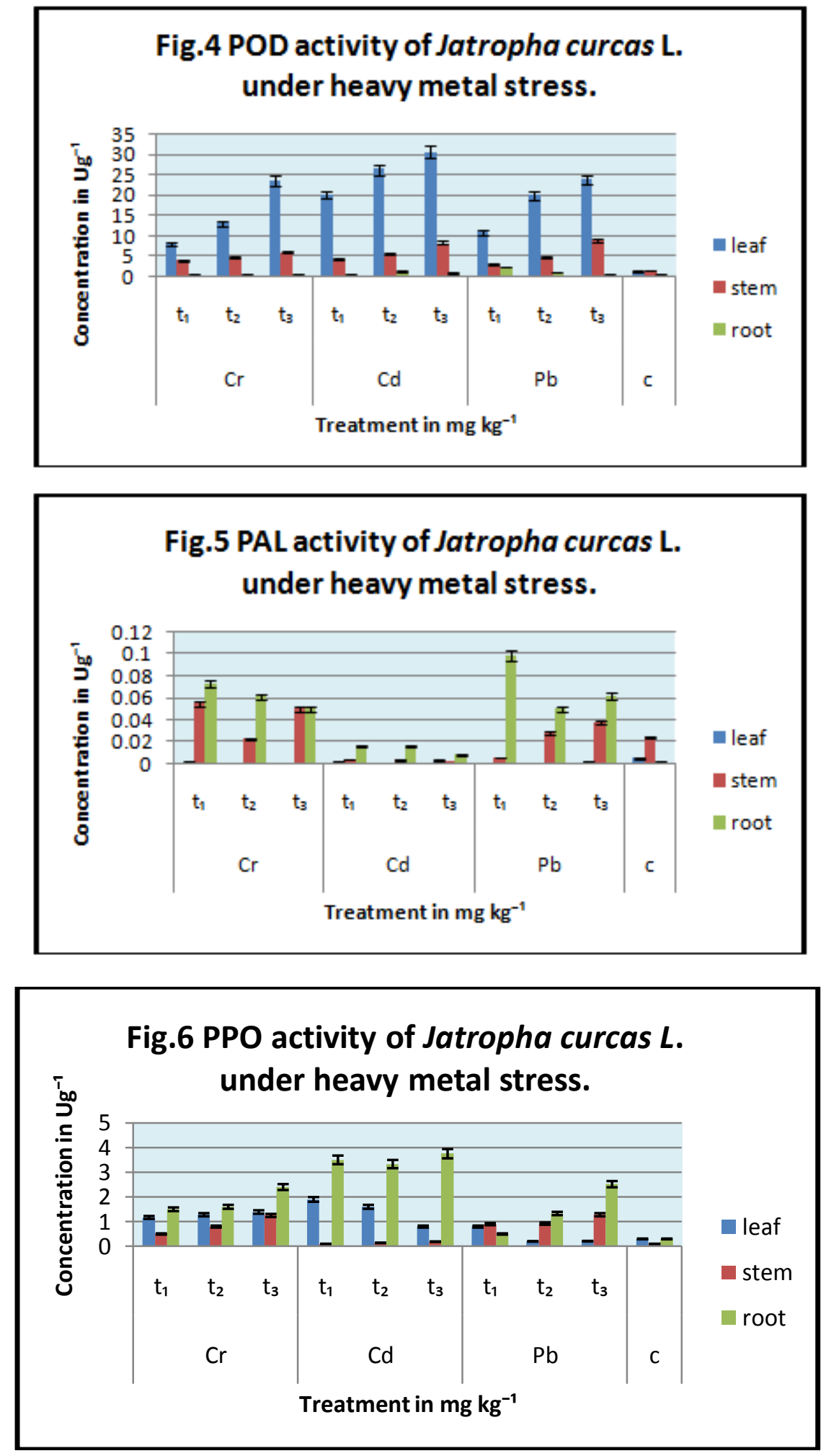
Fig.7 Proline contant in Jatropha curcas L. under heavy metal stress.

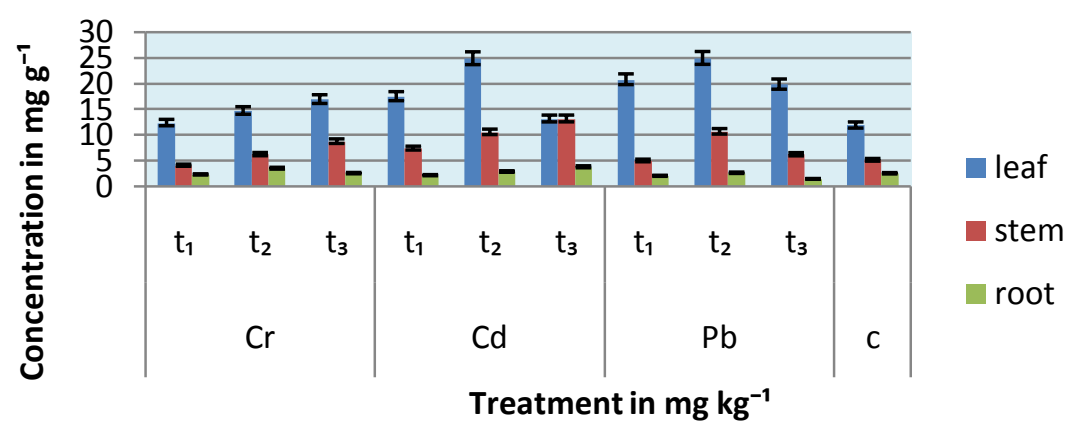

Fig.8 Chlorophyll a content of Jatropha curcas $L$. under heavy metal stress in leaf.
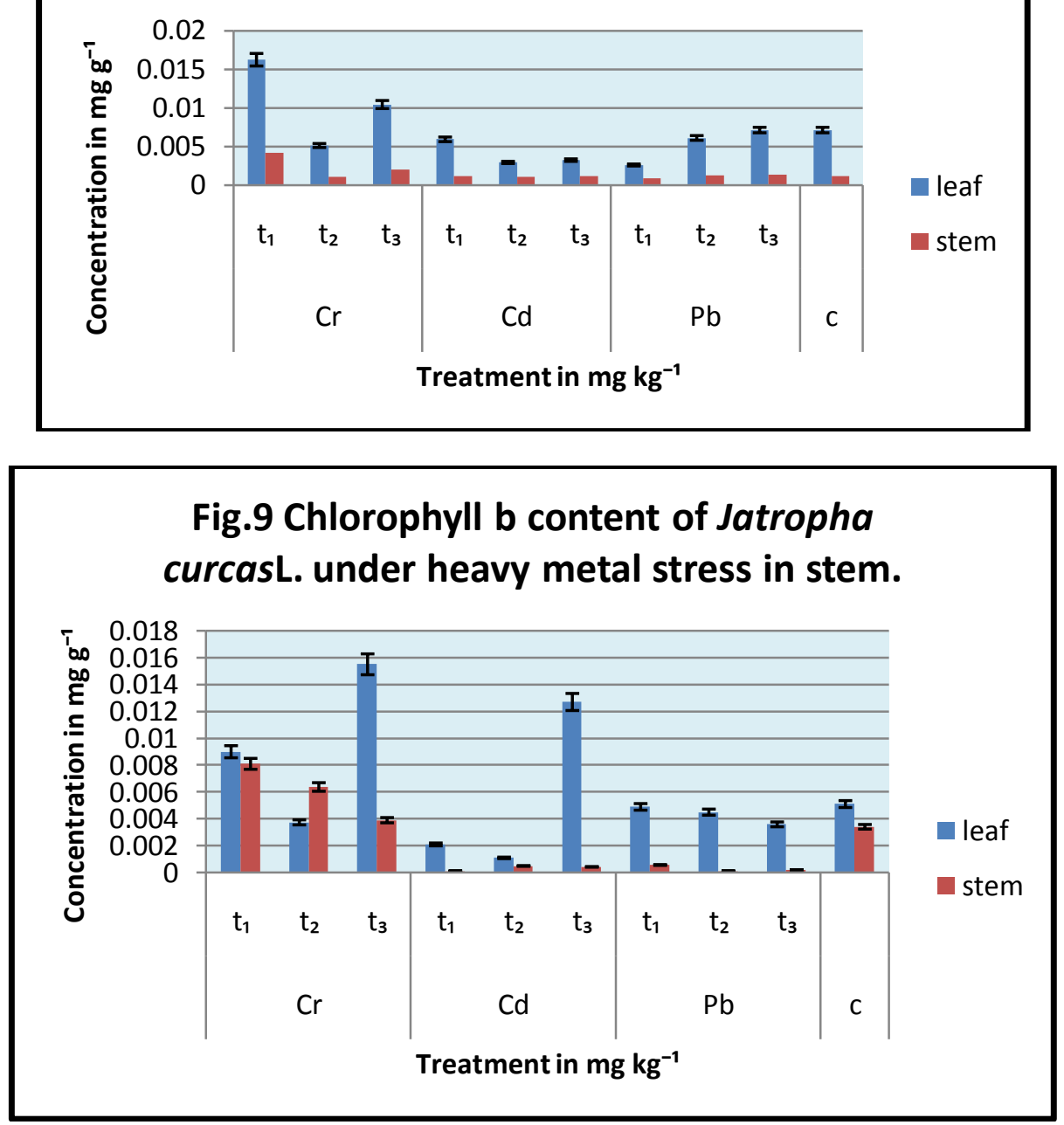

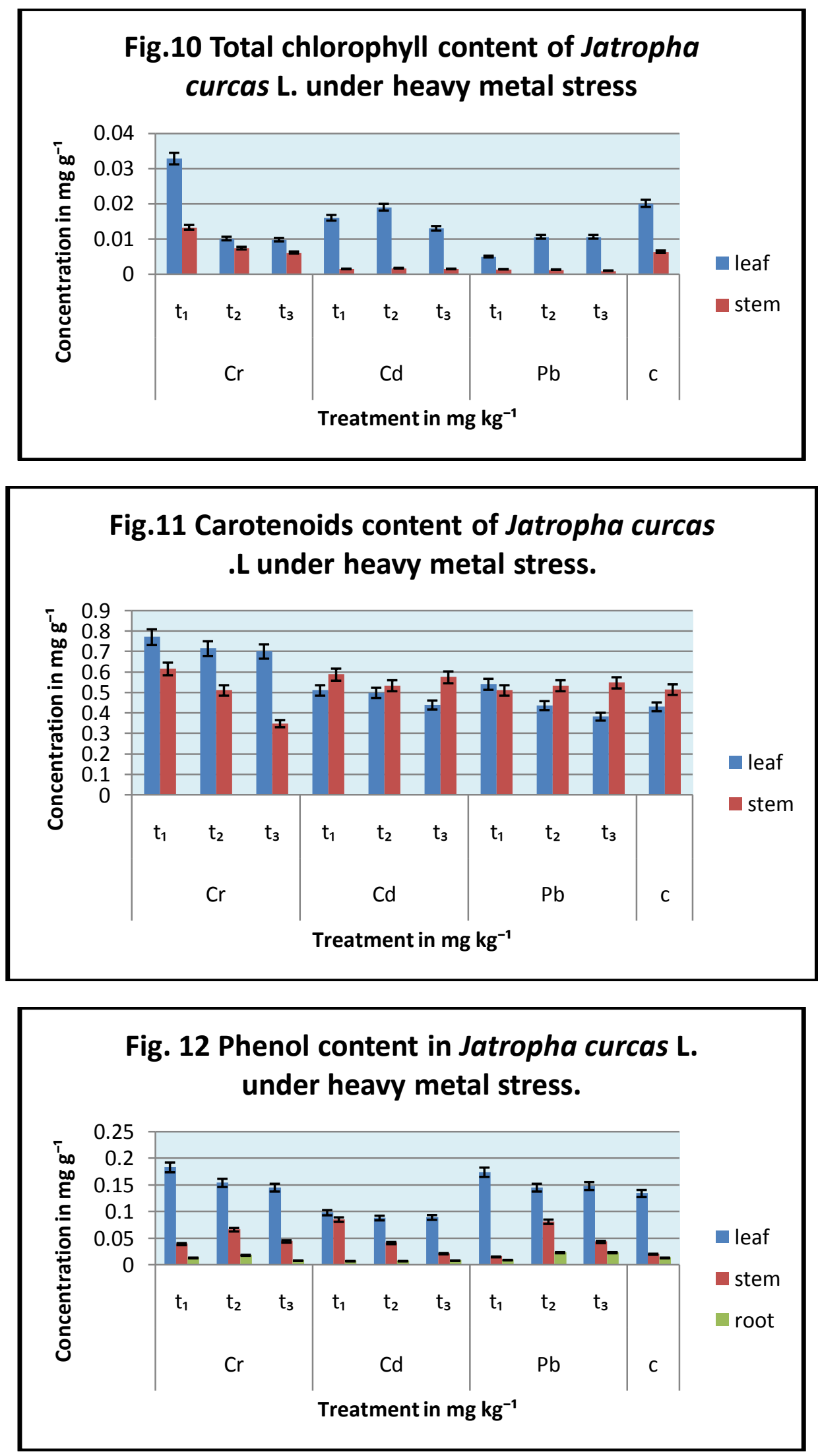

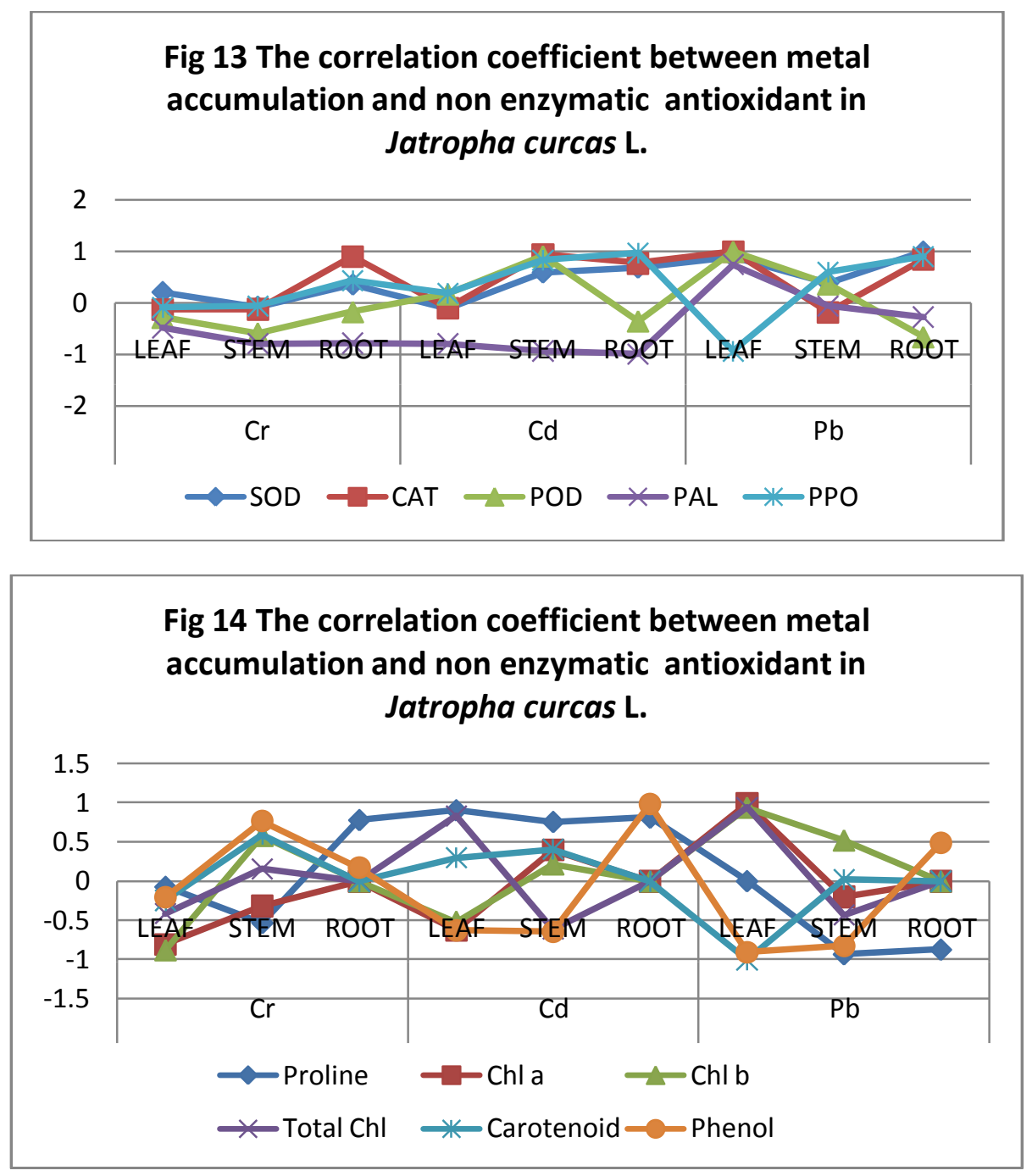